\title{
The Role of Educators, Parents and Students in the Face of Security Challenges in Nigeria
}

\author{
James Jacob, Ph.D \\ University of Abuja, Abuja, Nigeria \\ Email:jnjnda@yahoo.com, \\ Kabir Mato, Ph.D \\ University of Abuja, Abuja, Nigeria \\ Olusola E. Akintola \\ Transition Monitoring Group (TMG), National Headquarters, Abuja, Nigeria \\ Email: pgmprince@gmail.com
}

\section{Doi:10.5901/mjss.2015.v6n3s1p385}

\begin{abstract}
The sustainability of a political system depends on a complex of interactions and relationships of its components. The components and the structures of the system do not only help in boundary-maintenance but contribute to its development. This is applicable in Nigeria as the country is currently facing security challenges. In every geo-political zone in the country, security challenges abound; militancy in the Niger Delta, kidnapping in the South East, ritual killing in the South West and insurgency in the North. This demands that all hands must be on deck to curtail the challenges. It is consequent upon this that the authors examined the role of the educators, parents and students in the face of security challenges in Nigeria. Secondary source of data collection was adopted as our methodology. Through this method, explanatory and deductive analysis was made. The authors, therefore, submitted that what is needed mostly at this stage in our national life is less of talk, more of actions. All stakeholders should begin to act.
\end{abstract}

Keywords: educators, parents, students, security challenges, insurgency

\section{Introduction}

To state that Nigeria is going through an era of unusual security challenges is to state the obvious. Nigerians were unfamiliar with the kinds of threats to security of life and property that this country now experiences. While politicallymotivated assassinations are not somewhat new, Nigeria began to experience an unprecedented security challenge starting from the Niger Delta in the mid 1990s and now in the Northern part of the country.

Be that as it may, it is imperative to quickly make some clarifications about what this paper is trying to address. This is quite needful in the sense that issues of security are ambiguous. Security could be discussed in terms of food security, socio-economic security, job security, financial security, personal security, national security, among others. However, this paper addresses national security as it pertains to protecting the lives and property of Nigerians.

Accordingly, security is defined by an online dictionary, Wikipedia, as the act of keeping peace within the borders of a sovereign state or other self-governing territories. This is done generally by upholding the national law and defending against internal security threats. Essentially, national security has to do with the presence of peace, safety, happiness and the protection of human and physical resources or the absence of crisis, threats to human injury, among others (Otto and Ukpere, 2012:676). It focuses on the ability of a nation to protect her citizens against threats to their safety.

However, it should be noted that this is not the absence of some challenges. There is no such thing as 'perfect peace' as national security is concerned; it can only be defined as "the continued ability of a country to pursue its internal life without serious interference" (Cooley, 2011:63). It should be noted that insecurity, especially internal insecurity is not a problem that is unique to Nigeria. The United States, the United Kingdom and many other countries, face the challenges of insecurity within their borders on a daily basis. The difference between them and our country, Nigeria is how they manage the threats; how knowledgeable and prepared they are; how they deploy resources against the threats; 
how effective they are; how patriotic and united these people are against threats of insecurity (Adejumobi, 2011:1). Nigeria seems to take security of life and property of her citizens with levity.

This is against the fact that the 1999 Constitution (as amended) specifically states in Chapter 12, Section 14, (Fundamental Objectives and Directive Principles of State Policy) that the security and welfare of the people shall be the primary purpose of government. This places the responsibility of securing the lives and property of Nigerians on the Nigerian State. The developments in the recent years have proven to be the opposite.

Challenges of security in Nigeria have been in the forms of armed militancy, ethno-religious crises, insurgency, terrorism and bombings as manifested in the Niger Delta problem (which seemed to have died down a bit of recent as a result of the Amnesty Programme), Jos ethno-religious killings, Boko Haram massacres and bombings in the Northern parts of Nigeria, including the Federal Capital Territory, Abuja, among others.

The picture security challenges (especially with the spate of killings and bombings cum suicide massacres by the members of Boko Haram) in Nigeria seems to be painting is that the nation is under siege and that the security agencies no longer have the capacity to deal with the rising insecurity in the land. This calls for all hands to be on deck to check this. Hence, the importance of this topic "the role of educators, parents and stakeholders in the face of security challenges". What could the educators, parents as well as the students do not only to help in improving security situation in the nation but also protecting their lives and property? In what ways could the other stakeholders (the educators and the parents) help protect the students in the face of security challenges in Nigeria? The answers to these questions are the task of this paper. Before answering those questions, however, a theoretical analysis will be made.

\section{Theoretical Analysis and Methodology}

The theoretical framework adopted for the paper is system theory. The history of the theory can be traced to contributions from such seminal thinkers as Alfred North Whitehead, Ludwig von Bertalanffy, Anatol Rapoport, Paul A. Weiss, Ralph Gerard, Kurt Lewin, Roy R. Grinker, William Gray, Nicolas Rizzo, Karl Menninger, Silvano Arieti, etc (Laszlo and Krippner, 1998:2). In Social Science, it can be traced to Kenneth Boulding (an economist), and in Political Science, to David Easton.

In the broadest conception, the term system connotes a complex of interacting components together with the relationships among them that permit the identification of a boundary-maintaining entity or process (Laszlo and Krippner, 1998:7). And it should be noted that a system must satisfy the following criteria:

i. One can specify a set of identifiable elements.

ii. Among at least some of the elements, one can specify identifiable relations.

iii. Certain relations imply others.

iv. A certain complex of relations at a given time implies a certain complex (or one of several possible complexes) at a later time (Fisher, 2010:71).

Systems theory does much to render the complex dynamics of human bio-psycho-socio-cultural change comprehensible. Observed phenomena in the natural and human-made universe do not come in neat disciplinary packages labelled scientific, humanistic, and transcendental: they invariably involve complex combinations of fields, and the multifaceted situations to which they give rise require a holistic approach for their solution. Systems theory provides such an approach and can consequently be considered a field of inquiry rather than a collection of specific disciplines (Laszlo and Krippner, 1998:4). Since 'system' deals with forms of interrelated actions and interactions, the theory, therefore, can model complex intrapersonal, interpersonal, intergroup, and human/nature interactions without reducing perceptual phenomena to the level of individual stimuli. It capitalises on the emergence of parallelisms in different disciplinary interpretations of reality and consequently provides a platform for the integrated study of complexity in the human experience (Laszlo and Krippner, 1998:7).

In his contribution to the theory, David Easton claimed that systems analysis is especially suited for interpreting the behaviour of the members in a system in the light of the consequences this behaviour has for alleviating or aggravating stress upon the essential variables. It provides a way of determining the impact of the many diverse environmental influences on a system. In this way, it is possible to reduce the blow of stresses on the system and recommend appropriate action (Easton, 1966: 149 cited in Fisher, 2010: 73). Easton analyses this through the use of the concepts of inputs and outputs.

As for inputs, they include "any event external to the system that alters, modifies, or affects the system in any way" (Fisher, 2010: 73). The input analysis however focuses on two major inputs: demands and support. Demands are requests or claims made on the political system while supports are assistance or help rendered for the sustenance of the political system. These (demands and supports) affect the political system in no small way. 
Therefore, the role of educators, parents and students in the face of security challenges faced by Nigeria falls in the support side of system theory/analysis. As each of these important stakeholders in the Nigerian political system carry out their role, life and property in the country will be more secured; and Nigeria will experience political development. Also, the complex of interacting components together with the relationships among these stakeholders (educators train the students, parents provide support for the educators (through school fees and material support) and students, the future of the nation) will help in maintaining the sustenance or continuity of the Nigerian political system.

Therefore, in order to drive home the above and achieve the objective of this study, which is to examine the importance of parents, educators as well as students in confronting security challenges in Nigeria, the authors adopted secondary source of data collection. Data was collected through documentary sources like books, journals and internet materials. To analyse the data, explanatory and deductive method was used. This was done in order to evaluate the usefulness and relevant of the data to the study.

\title{
3. Literature Review
}

Security is the main concept in this study. However, it is not all forms of security that are the focus here. This is because security has dimension - human security, political security, job security, environmental security, marriage security, among others. As far as this study is concerned, the focus is mainly on the national security. Generally, security, according to Anyadike (2013:13), is a situation where a person or thing is not exposed to any form of danger or risk of physical or moral aggression, accident, theft or deterioration. It can be deduced from this definition that security is all about freedom from anything that exposes one or a thing to discomfort that could disfigure.

In line with the above, Hussein, Gnisci and Wanjiru (2004:14) summarily argue that:

Security is increasingly viewed as an all-encompassing condition in which people and communities live in freedom, peace and safety, participate fully in the governance of their countries, enjoy the protection of fundamental rights, have access to resources and basic necessities of life, and inhabit an environment which is not detrimental to their health and well being...the security of people and the security of the State are mutually reinforcing.

And in fact, security "embraces all aspects of the society including economic, political and social dimensions of individual, family, community, local and national life" (Hussein, Gnisci and Wanjiru, 2004:15). In this, national security can be located. This is because it encompasses all aspects of national life and covers every aspect of life of the people that make the society.

Consequently, Nwanegbo and Odigbo (2013:286) argue that national security is the freedom from or the absence of those tendencies which could undermine internal cohesion and the cooperate existence of the nation and its ability to maintain its vital institutions for the promotion of its core values and socio-political and economic objectives, as well as meet the legitimate aspirations of the people.

Braithwaite (1988:9) quoting the encyclopedia of the social sciences defines national security as "ability of a nation to protect its internal values from external threat". Also, Lipmann defines it by stating that "a nation has security when it does not have to sacrifice its legitimate interest to avoid war, and is able, if challenged, to maintain them by war" (cited in Anyadike, 2013:13). The perception here is about national defence. It centres on freedom from external aggressors.

However, from another perspective, national security is perceived differently. According to Ibeanu and Momoh (2008:13):

\begin{abstract}
National security is equated to state security, and state security is viewed as the security of those who occupy public office. Rarely is national security viewed as the welfare and happiness of the citizens, neither is security viewed as 'community security', 'societal security' or securing the 'common good', defined in the most generic way. In other words, security is viewed in purely state-centric and military terms and not in social and developmental terms; it is perceived as the maintenance of state sovereignty, not in the context of a common humanity and promoting the welfare of the people.
\end{abstract}

Analysing the above in line with what other scholars have argued, national security can be seen as the protection of the ruling class from all the tendencies that could cause division among them and could threaten national cohesion through them as they tend to manipulate the values of the majority for their benefits. In order words, national security is ensuring internal cohesion and unity in order to protect the citizenry (both ruling and non-ruling class) from internal and external threats. Little wonder, the stakeholders in national security are not only the ruling class or the elite. In fact, they are not only law enforcement agencies and institutions of government but "other non-State actors that could be considered as part of the security sector include customary or informal authorities and private security services" (United 
Nations, 2012:2). The educators, parents and students, therefore, fall among the informal authorities that are germane in guaranteeing national security. This is the option that the authors advocate that Nigeria should explore. In fact, these stakeholders are important in confronting the current national security challenges in Nigeria. Before going into the details of this, there is a need to look at the overview of security challenges in Nigeria. To this we now turn.

\section{The Overview of Security Challenges in Nigeria}

As earlier alluded to, security challenges that have been experienced, especially since 1999, in Nigeria can be categorised under some headings which include ethno-religious and communal violence, political assassination, electoral violence, armed militancy and insurgency or Boko Haram terrorism.

Nigeria has witnessed various ethno-religious and communal violence in the recent years. These include Jos crisis and the conflict between farmers and herdsmen. On Friday, March 14, 2014, the indigenes of Angwan Sakwai, a rural community in Kaura Local Government Area of Kaduna State, were attacked by Fulani herdsmen. The once peaceful agrarian community was invaded by Fulani herdsmen and at the end of the attack, no fewer than 57 innocent residents were sent to their early graves (Kumolu, 2014:1).

Also, there have been escalations of reported attacks by Fulani herdsmen who brutally kill natives of the invaded farming communities including women and children in various states across the country. The Fulani herdsmen armed with sophisticated weapons usually attack their target communities at the time they are most vulnerable such as mid-night or on Sundays when they are in their churches, killing people indiscriminately, mostly women and children, burning houses and looting properties. Benue, Taraba, Nassarawa, Plateau, Kaduna, Katsina have been the worst hit of late having tasted the devastating attacks by the Fulani herdsmen with heavy toll in human lives and property and still counting their loses (Daily Independent, Editorial; Saturday, July 12, 2014). This is how insecure communities in Nigeria have become.

Political assassinations have also come in different dimensions and ways. Examples of these types of security challenges include the killing of Odunayo Olagbaju in December 2001, Chief Bola Ige in 2001, Barrnabas Igwe and his wife in 2002, Dr. Harry Marshal; a Senior Advocate of Nigeria and Chief Ajibola Olanipekun. Others are People's Democratic Party's (PDP) Vice Chairman in the South-South, Aminosari Dikibo; Engineer Funso Williams; Dr. Ayo Daramola; and Olaitan Oyerinde a popular labour activist and principal secretary to the Governor of Edo State Adams Oshiomhole, who was murdered in cold blood on May 3, 2012 by yet unknown gunmen (Albert, 2014:3). This is coupled with the electoral violence especially since 2003 general elections.

Electoral violence became rampant in 2003, 2007, and 2011 general elections. The violence took place before and during elections except that of 2011 which was post election. Most of the violence is caused by political thugs sponsored by politicians. Examples of these groups are Adedibu boys in Oyo state; "Gbosa boys" in Kwara; Yan tauri and Yan banga in Kano; Yan Kalari in Gombe; Sara Suka in Bauchi (Albert, 2014:4). All of these youth gangs were formed and funded by politicians, and they have caused untold hardship to Nigerians. Their activities have left families scattered, turning people to widows and orphans just for the political ambitions and self-centredness of their sponsors. And it has been said that at least more than 800 people were said to have been killed in these electoral violence (Adejumobi, 2011:3).

Armed militancy is identified with the Niger Deltan youths. Some of the militant groups in the region are the Movement for the Survival of Ogoni People (MOSOP); Movement for the Emancipation of the Niger Delta (MEND); Niger Delta People's Volunteer Force (NDPVF), the Egbesu Boys, Niger Delta Vigilante, Movement for the Survival of ljaw Ethnic Nationality (MOSIEN), among others (Obioma, 2013:4). These groups have a long history dating back to the Adaka Boro movement in the 1960s to Ken Saro Wiwa's struggles. Put together, it is essentially a militant agitation against environmental degradation, unemployment, poverty, deprivation and marginalisation.

These groups usually engage in oil theft, illegal oil bunkering and sea piracy, kidnapping, hostage taking (Albert, 2014:3), pipeline vandalisation, arson and ambush. Till date, more than five hundred oil workers, politicians, actors, children, and other important personalities have either been kidnapped or taken hostage. They use hostage taking as proxies to get government attentions, as the groups focus more on the ransom paid to ensure release of the oil industry workers (Oyeniyi, 2010:8). These groups have also fought the government forces on many occasions and also sabotaged oil installations.

It should be noted however that although these forms of inhuman activities (especially kidnapping and hostage taking) started in the Niger Delta, it has now spread everywhere with the South East and Delta State in the Niger Delta being the most notorious. Kidnapping and hostage taking have made insecurity in the South East and South-South of the country worse. This goes to prove that insecurity in Nigeria is a national malaise, but not a preserve of any region or 
ethnic group; it is the volume and extent of the insecurity that is just different. What now attracts attention of every Nigerian and foreigners is the Boko Haram insurgency.

The extremist Islamic group, Boko Haram, operates majorly in the northern part of the country. The group has launched several deadly attacks on Nigerian State killing many Nigerians. Institutions of the state (the police, the armed forces, and schools), places of worship, relaxation centres, etc, have been attacked by the group especially since it began its operations, and these have led to many losses of lives (Jacob and Akintola, 2014:206).

In 2011 alone, Boko Haram struck 115 times and killed 550 people. Within the first three weeks of 2012, the sect killed 250 people with the deadliest being the coordinated bombings in the ancient city of Kano, which claimed 185 lives. A few weeks later another 12 people were killed in a shoot-out between the Joint Task Force (JTF) and members of the sect in Maiduguri, Borno State (cited in Jacob and Akintola, 2014:206). These do not include the many recent killings resulting from incessant bombings and suicide attacks.

In addition to the above, there have also been the series of recent killings of students and children by Boko Haram ranging from the July 62013 attack at Mamudo Government Secondary School in Yobe where at least 41 children and one teacher were killed; the 29 September 2013 Gujiba College massacre where suspected gunmen entered the male dormitory in the College of Agriculture in Gujiba, Yobe State, killing at least 44 students and teachers; the Baga massacre of April 19 to 20, 2013 in Borno State where over 228 people were murdered as well as the first major onslaught on March 8, 2010 in the Dogo Nahawa in Plateau State where more than 500 villagers including several children were killed in cold blood. Also, there are examples of the killings of an estimated 50 students of the Federal Government College in Buni Yadi, Yobe State in the early hours of February 25, 2014 by suspected members of the extremist Boko Haram (Sahara Reporters, February 26, 2014). This does not include several unreported killings there are going on ever since then.

One thing that needs to be pointed out here is the consequences of these wanton killings; it has not only increased the level of insecurity of life and property but has also led to multiplier effects in some other aspects of Nigeria's national life. Some of the negative multiplier effects of this, according to Eme and Onyishi (2011:179), are:

i. Social dislocation and population displacement;

ii. Social tensions and new pattern of settlements which encourages Muslims/Christians or members of an ethnic group moving to Muslim/Christian dominated enclaves;

iii. Heightens citizenship question and encourages hostility between "indigenes" and "settlers";

iv. Dislocation and disruption of family and communal life;

v. General atmosphere of mistrust, fear, anxiety and frenzy;

vi. Dehumanisation of women, children, and men especially in areas where rape, child abuse and neglect are used as instruments of war;

vii. Deepening of hunger and poverty in the polity;

viii. Atmosphere of political insecurity and instability including declining confidence in the political leadership and apprehension about the system; and

ix. Governance deficit as a result of security agencies inefficiency and corruption.

What the current trend of violence is imprinting on the psyche of Nigerians is that the government security apparatus is incapable of guaranteeing the safety and security of its people. This would, therefore, impact on the general human security of the people as the situation promotes fear, while at the same time limiting the peoples' ability to develop economically (Adejumobi, 2011:2). This pitiable level of insecurity in the country now calls for everyone to be alert and play his/her roles in ensuring the sanctity of human life. This will lead to addressing the roles that the educators, parents and students can play in the addressing security challenges in Nigeria.

\section{The Stakeholders in the Face of Security Challenges in the Country}

Now that the security of the individuals is more participatory (between the citizens and the government), every Nigerian is a stakeholder. However, the roles of the three of these stakeholders will be brought to the fore as concerning security challenges in Nigeria.

\subsection{Educators}

The first question to ask here is 'who is an educator?' An educator, according to the American Heritage Dictionary of the English Language, is that individual trained in teaching; that is a teacher. He/she is also conceived to be a specialist in the theory and practice of education or an administrator of a school or an educational institution. It goes without saying 
that an educator has so much influence, because of his/her exposure (to knowledge) and individuals that he/she comes in contact with (because of his/her grasp of issues of life).

One important thing to bear in mind, which makes educators great assets to Nigeria at this trying period, is what Siraj-Blatchford (2014) points out. She submits that educators are not just teachers; they are people who support learning. They are practitioners who work directly with learners. When it comes to the young ones, an educator is the one who sculpts the young child with much craft - not according to the educator's way, but rather by the child's way. Therefore, an educator ought to be a very special person, with a very broad outlook on life and an understanding of the processes that are happening in the world (ARI Institute, 2014). Through a familiarity with the world and with nature, he should have a clear vision of the state he would like to bring the child to at the end of the educational process. How could the educators, therefore, help in ensuring secured Nigeria?

All educators at all levels of Nigerian educational system should be consistent in promoting morality and ethical values while imparting knowledge on students. Morality and ethical values would not only help in bringing up the students to contribute effectively to the development of the society, it would also promote tolerance among them. This is based on the fact that no society or community in any part of Nigeria upholds violence or act of hooliganism. In fact, decadence in ethical values and morality in our society contributes immensely to incessant violence in the country.

Educators at all levels of education should also serve as good exemplary leaders to the students by demonstrating ethical values of kindness, tolerance, forgiveness, and consideration for others in all circumstances. This becomes very important because most violence and civil disturbance, even quarrel in the neighbourhood is mostly built on lack of forgiveness. Intolerance is deeply rooted in the fact that most people find it difficult to consider others in their actions, which lead to disagreement, conflict and crisis. And as a result of this, insecurity is deepened.

Educators become important in this bearing what has been said earlier about an educator in mind; that through his familiarity with the world and with nature, he/she has a clear vision of the state he would like to bring the child to at the end of the educational process. The educator is in the best position to teach and demonstrate (through his/her lifestyle among his/her students and those he/she has influence on) the virtue of forgiveness and tolerance. Consequently, the level of insecurity will be reduced to the barest minimum in our society.

Educators also have a role to play in relation to the government. They are best placed to advise the government that all obstacles that may hinder practical implementation of the moral values taught through them should be removed. Obstacles like unemployment, poverty, hunger, high level of inequality, among others. It is a well known fact that "a hungry man is an angry man". The educators should suggest practical ways through which these pitiable human conditions among Nigerians will be reduced. This is because if high level of unemployment among the youths are reduced and poverty is dealt with; most of the young Nigerians that are involved or recruited to cause mayhem, maiming and killing would have been gainfully and positively engaged.

Religious educators have special roles to play. It is important now for a conscious attempt to re-read; re-examine and re-interpret the Holy Scriptures (both the Bible and Quran). Also, religious doctrines need to be re-examined and reinterpreted in our society to make not only the students but every Nigerian religiously tolerant. Ours is a country that is religion sensitive, and this is based on indoctrination and teachings of the two most popular religions in Nigeria; Christianity and Islam. Religion educators or teachers should begin to emphasise peace as taught through these Holy Scriptures. These will make these religions more meaningful toward establishing an egalitarian society, where all people will be at peace with each other. Proper positive religious education and orientation is to be given, so that ignorance can be wiped out.

In addition, at school, comparative religion can be thought to enable students compare and contrast different religions with emphasis laid on areas of agreement, tolerance and security of lives and properties. This will help to eradicate ignorance and engender mutual understanding (Olawale, and Yemisi, 2012:4). Lack of proper understanding is the bane of religious bigotry and fundamentalism. This can be traced to the existence of Boko Haram sect that is now the source of the greatest insecurity in Nigeria. Therefore, religious teachers or educators should preach and teach the word of God in its true meaning to the students and not mislead them through negative indoctrination and zealotry. This would help re-orientate Nigerians to see each other as brethren and compatriots no matter their religious differences.

There is a need for the educators to be more equipped theoretically and practically on the issues of security. Now that Nigeria has a unique form of security challenge (terrorism and suicide bombing by Boko Haram sect) educators also need to create a common forum for exchange of idea and understanding, consensus building and cooperation through seminars, workshops and conferences. Because their position is unique and strategic, they should be well informed on how to help in case of insecurity; for if they are not well informed, how can they inform others?

As administrators of schools or educational institutions, educators are to help discourage the deliberate and mutual use of arms in resolving conflicts and disputes arising among students. They should use all forms of communication to 
drum it hard to the students - through orientation, students' counsellors, special lectures, among others. In addition, consequences of using arms should be properly spelt out to them. With all of these, educators will be of great help in the face of security challenges Nigeria is currently passing though.

\subsection{Parents}

Parents are also strategic in the move to make Nigeria more secure. As they raise their children and wards, they help them inculcate habits and behaviours that help build or mar the society. Parenting is very fundamental in shaping the attitudes and behaviour of the individuals because it exposes children to various things during their formative years. And it should be noted that the process of raising and educating a child starts from birth until adulthood. In the face of security challenges Nigeria is passing through, the roles of parent and parenting cannot be overemphasised.

At home, parents should promote the ethical values of tolerance. They should demonstrate this by being good neighbours in the neighbourhood. This becomes imperative because children learn by examples, especially those from their parents. Children seem to behave and say "if my parents do it, it is right; if they don't, it is wrong". If parents promote tolerance, especially among their neighbours who are of different ethnic and religious background, strives would reduce and peace would reign. This would be definitely transferred to the community.

In addition, at home, parents and siblings are to encourage folk stories that stress tolerance, endurance, justice and peaceful co-existence among mankind. This would drive home all the teachings and encouragement that the parents are trying to pass to them. This should be encouraged (folk stories telling) especially at the formative stage of the children because it will be very hard for them to forget it as they grow up.

Parents should teach their children and wards the genuine words of God from the Holy Scriptures (both the Bible and Quran). Like it was said of the educators, parents should begin to emphasise those aspects of the Scriptures that enjoin and admonish peaceful co-existence in the society. Since every Nigerian comes from a family, it will not take long before every nook and cranny of this country is positively affected with these teachings. With this, our society would be more secured, and each one would become his/her brother and sister's keeper.

Another thing that parents need to do is to teach their children and wards how to be security conscious. While they teach this, they should also demonstrate this at home by being security conscious. In and around the house, security lights should be properly put in place. They should cooperate with their neighbours (in terms of if need be having private security arrangement, reportage to the security agencies of people noticed to be of suspicious characters, among others) in seeing that the neighbourhood is secured from all manners of threat.

In addition, parents are in the position to teach their children what could be termed 'first aid security measures' in case of any emergency. One of these measures could be lying down flat on the ground in case there is sound of bullets from place close by. Another one could be telling their children not to go and watch what is happening in case of any bomb explosion or any explosion at all. Experiences of bomb blasts masterminded by Boko Haram has taught us that more people are killed when they go and watch what happened at explosion site; for there have always been another one planted close by, which always claim more causalities than the first as people go to see what is happening. The recent bomb blast in Jos (which happened close to University of Jos Teaching Hospital) is a case in point. If parents do this, it will help in the face of security challenge that Nigeria is passing through.

To conclude this, parents should be good observers of their children and wards. This would help them to know whenever their children are manifesting strange characters that could be threats to not only them but that of the neighbourhood and the country at large. Lack of vigilance by some parents has made their children (the case of Abdulmutallab, who attempted to bomb a US airplane is a case in point) go wayward, even under their nose. While it is natural for a child to want to be identify with his peer and therefore do certain things that are antithetical to family and society values; it is the duty of the parents to correct the child through care, gentleness and in the fear of God. What could the students do to help as well?

\subsection{Students}

Most of what students need to do is tied to actions. They are taught from school (by the educators) and at home (by the parents); they need to put all of these into practice. It is not in listening to all of these that they could help reduce security threats in Nigeria; it is actually in what they do with all what they learn.

First of all the students need to do is not use their own ethnic and historical background to condemn and criticise other people who have different process of socialisation. They should tolerate others from different religion, ethnic and historical setting. This would promote the values of tolerance and co-existence in Nigeria. And as this is promoted, 
security is enhanced; for no one would see the need to hate the other person since there is mutual understanding.

The students should be encouraged to demonstrate such religious, moral and ethical values that strengthen peaceful coexistence among themselves. In their day to day dealings or affairs with other fellow men, they should not be perceived as religious bigot or full of ethnic chauvinism. This would help reduce ethno-religious violence that has become the order of day in places like Jos and Kaduna.

Furthermore, students should be security conscious. They should report unwholesome practices noticed among their mates to the authorities, either in the school or to the security agencies. They should be vanguards of promoting security awareness in their midst.

In case of grievance among the students, each of them should allow one another to express themselves and ask questions. They should not allow anger to be bottled up. Bottled anger could explode and lead to riot, unrest and even, violence. Among the students' leaders, equal rights and freedom of all students should be guaranteed. This would not only give everyone of them a sense of belonging, it would also guarantee an atmosphere free of unrest and violence.

\section{Conclusion}

As it has been pointed out, security is no more only the business of the government. Other stakeholders and non-state actors, especially the informal authorities (United Nations, 2012:2), needed to guarantee the protection of life and property of citizens are educators, parents and students. Therefore, all hands must be on deck to guarantee the safety of life and property of Nigerians. Gone are the days when citizens would fold their hands and expected the government to do everything for them. For everyone to be safe and secured, security has become the business of all citizens.

It is in the light of the above that the roles of educators, parents and students in the face of security challenges in Nigeria were examined. Each of these stakeholders is very strategic in dealing with security threats that the country now faces. While the insurgency of Boko Haram sect is the most popular, each section of this country has a peculiar form of security threat that must be wary of - there is militancy in the Niger Delta, kidnapping in the South East, ritual killing in the South West and insurgency in the North. This has led to formation of various ethnic-based militia groups - Oodua People's Congress (OPC) in the West; Arewa Consultative Forum (ACF) in the North; in the East, the Bakassi Boys, Bakassi Movement for Self-determination; Igbo People's Congress; and Movement for the Actualisation of the Sovereign State of Biafra (MASSOB) in the south-south (Emuedo, 2012:142; Obioma, 2013:2). The proliferation of these militia groups is not only threat to Nigerians' lives but also their economic sustenance (Adejumobi, 2011:2).

Therefore, what is needed mostly at this stage in our national life is less of talk, more of actions. All stakeholders should begin to act. Suggestions that have been put forward here should be put into practice, and government should also swing into action. The present administration should demonstrate the political will to deal with every act of anti-state practice which threatens the corporate existence of Nigeria. The time to act is now.

\section{References}

Adejumobi, A. (2011). The Problems and Challenges of Insecurity in Nigeria. Text of a Paper Presented to ACN UK General Meeting, 10th September 2011, London, UK. Retrieved from http://chatafrik.com/articles/nigerian-affairs/the-problems-and- challenges-ofinsecurity-in-nigeria

Albert, I. O. (2014). Explaining the Security Challenges in Contemporary Nigeria. Ibadan: Institute of African Studies. Retrieved from www.nisngr.com/sites/nisn/files/conferences/fellow\%20investiture.pdf

Anyadike, N. O. (2013). Boko Haram and National Security Challenges in Nigeria: Causes and Solutions. Journal of Economics and Sustainable Development, 4(5):12-23.

ARI Institute (2014). A Teacher Who is First and Foremost an Educator. Retrieved from http://ariresearch.org/education-principles/ateacher-who-is-first-and-foremost-an-educator

Cooley, K. W. (2011). Energy Security Is National Security. In Ronis, S. R. (ed) Economic Security: Neglected Dimension of National Security? Washington, D.C.: National Defence University Press.

Daily Independent Editorial (Saturday, July 12, 2014). Challenge of Fulani Herdsmen. Retrieved from http://dailyindependentnig. com/2014/03/challenge-of-fulani-herdsmen/

Eme, O. I. and Onyishi, A. (2011). The Challenges of Insecurity in Nigeria: A Thematic Exposition. Interdisciplinary Journal of Contemporary Research in Business, 3(8).

Emuedo, C. G. O. (2012). Ethnicity and Conflicts in Nigeria A Fait Accompli? An Examination of the Oil-Related Conflicts in the Niger Delta. Nigerian Journal of Social and Development Studies, Vol.9, No. 2, June 2012, pp. 140-156.

Federal Republic of Nigeria: 1999 Constitution (as amended) of the Federal Republic of Nigeria. Lagos: Federal Government Printer.

Fisher, J. R. (2010). Systems Theory and Structural Functionalism. In Ishiyama, J. T. And Breuning, M. (eds) 21st Century Political Science: A Reference Handbook (Volume 1). Los Angeles: Sage. 
Hussein, K., Gnisci, D. and Wanjiru, J. (2004). Security and Human Security: An Overview of Concepts and Initiatives What Implications for West Africa? Organisation for Economic Cooperation and Development (OECD) Issues Paper. Paris: OECD.

Ibeanu, O. and Momoh, A. (2008). State Responsiveness to Public Security Needs: The Politics of Security Decision-Making, Nigeria Country Study. Conflict, Security and Development Group (CSDP) London Papers, 14:1- 75.

Jacob, J. and Akintola, O. E. (2014). Foreign Policy and Terrorism in Nigeria: An Impact Assessment of the Activities of Boko Haram Sect on Nigeria's External Relations. In Nwoke, C. N. and Oche, O. (eds) Contemporary Challenges in Nigeria, Africa and the World. Lagos: The Nigerian Institute of International Affairs.

Kumolu, C. (2014). Fulani Herdsmen, Farmers Clashes: Furore over Grazing Reserves. Vanguard Newspaper, April 09, 2014; retrieved from http://www.vanguardngr.com/2014/04/fulani-herdsmen-farmers-clashes-furore-grazing-reserves/

Laszlo, A and Krippner, S. (1998). Systems Theories: Their Origins, Foundations and Development. In Jordan, J. S. (ed) Systems Theories and A Priori Aspects of Perception. Amsterdam: Alservier Science.

Nwanegbo, C. J. and Odigbo, (2013). Security and National Development in Nigeria: The Threat of Boko Haram. International Journal of Humanities and Social Science, 3(4):285-291.

Obioma, J. D. (2013). Boko Haram, Domestic Terrorism and the Future of Nigeria.The Economy Magazine: Lagos Development Economic Resource (D.E.R.) Ltd Retrieved from http://theeconomyng.com/news155.html

Olawale, S. K. and Yemisi, O. M. (2012). The Roles of Religious Education to Peace, Security and Sustainable Development in Nigeria. IOSR Journal of Humanities and Social Science (JHSS), Volume 3(6).

Otto, G. and Ukpere, W. I. (2012). National Security and Development in Nigeria. African Journal of Business Management, 6(23).

Oyeniyi, A. B. (2010). Terrorism in Nigeria: Groups, Activities, and Politics. International Journal of Politics and Good Governance, 1(1), Quarter 1, 2010.

Sahara Reporters (February 26, 2014). Killing Of Children by Boko Haram: Government Not Doing Enough, Say Groups. Retrieved from http://saharareporters.com/2014/02/26/killing-children-boko-haram-government-not-doing-enough-say-groups.

Siraj-Blatchford, I. (2014). The Role of the Educator in the Early Years. Retrieved from www.internet.ceo.wa.edu.au/.../Early\%20 Years\%20and\%20Care The\%20Role....

United Nations (2012). UN Security Sector Reform Perspectives: Sustainable Peace through Justice and Security. New York: UN. 